\title{
SISTEM PENCATATAN DATA PASIEN KANKER DI RSUP DR.SARDJITO
}

\author{
Savitri Citra Budi \\ Rekam Medis Sekolah Vokasi UGM \\ vi3ku@yahoo.com / 0818464401
}

\begin{abstract}
ABSTRAK
Rekam medis adalah berkas yang berisikan catatan dan dokumen tentang identitas pasien, pemeriksaan, pengobatan, tindakan dan pelayanan lain yang telah diberikan kepada pasien (Permenkes nomor 269 tahun 2008). Penyakit kanker sebagai salah satu penyebab kematian pasien di rumah sakit. Penyakit ini membutuhkan penanganan yang lama dan berkelanjutan sampai tuntasnya pengobatan. Tujuan penelitian ini untuk mengetahui sistem pencatatan data pasien kanker di RSUP Dr. Sardjito. Jenis enelitian ini adalah deskriptif dengan pendekatan studi kasus. Teknik pengumpulan data menggunakan observasi, wawancara dan studi dokumentasi.Validitas data penelitian dengan triangulasi metode. Hasil penelitian menunjukkan bahwa Sistem pencatatan data pasien kanker di Instalasi Kanker Tulip dilakukan pada berkas rekam medis dan register kanker. Berkas rekam medis di Instalasi Kanker Tulip dikelola terpisah dari Instalasi Catatan Medis RSUP Dr.Sardjito. Instalasi Kanker Tulip belum melakukan kegiatan assembling, coding, dan indeks untuk menjamin kelengkapannya. Registrasi kanker dilakukan pada aplikasi komputer yang bernama SRIKANDI (Sistem Registrasi Pasien Kanker di Indonesia). Pelaksanaan pengumpulan data dengan SRIKANDI belum dapat berjalan secara real-time. Persentase paling tinggi untuk ketidakterisian pada 4 komponen analisis kuantitatif terdapat pada lembar poliklinik dan asuhan keperawatan yang nilainya lebih dari $60 \%$. Hasil analisis item pada register kanker ditemukan $100 \%$ data pada tanggal follow-up tidak terisi. Kendala sistem pencatatan data pasien kanker terdapat pada petugas, prosedur, fasilitas, dan sumber data.
\end{abstract}

Kata Kunci : berkas rekam medis, register kanker, pasien kanker, pencatatan data pasien kanker.

\section{PENDAHULUAN}

Kedaulatan pemerintah diperlukan untuk mendukung manajemen penanganan penyakit kanker yang baik. Penguatan konpetensi petugas rekam medis dalam melakukan manajemen rekam medis pasien kanker sebagai salah satu upaya membantu tenaga medis dalam penanganan pasien kanker. Membudayakan mengelola rekam medis yang lengkap, terkini dan dapat ditemukan saat digunakan kembali merupakan tujuan penyelenggaraan rekam medis. Berdasarkan UU Nomor 29 tahun 2004 tentang Praktek Kedokteran, disebutkan bahwa setiap dokter dan dokter gigi dalam menjalankan praktek kedokteran wajib membuat rekam medis.

Beberapa penyakit tertentu memerlukan manajemen data khusus selain yang sudah terdapat dalam rekam medis, misalnya penyakit kanker. Register kanker diperlukan untuk dapat memberikan pelayanan yang tuntas kepada pasien. Menurut
Johns (2002) pada register kanker dapat digunakan untuk mengumpulkan informasi dalam jangka waktu lama (dari awal pengobatan sampai akhir penanganan penyakit kanker) yang dibutuhkan untuk menegakkan diagnosis dan penanganan pasien kanker.

Penelitian ini sesuai dengan prioritas riset yang telah ditetapkan oleh Senat Akademik UGM khususnya tentang penguatan dan pendayagunaan budaya lokal. Khususnya penguatan kompetensi petugas dan pendayagunaan budaya lokal untuk penanganan pasien kanker di RSUP Dr.Sardjito Yogyakarta. Tuntuk ujuan penelitian ini adalah mengetahui sistem pencatatan data pasien kanker di Instalasi Kanker Tulip RSUP Dr.Sardjito.

Menurut Huffman (1994) register kanker diadakan untuk pengumpulan dan pemeliharaan data pelayanan pasien yang komprehensif pada semua pasien kanker. Tujuan utama pembuatan register kanker ini adalah untuk menyediakan data berkelanjuta 
seumur hidup pasien kanker dan untuk menyediakan informasi yang berguna bagi tenaga kesehatan untuk melakukan evaluasi pelayanan pasien dan penelitian terkait pasien kanker.

Dregan, at.al (2012) dengan judul Validity of Cancer Diagnosis in a Primary Care Database Compared with Linked Cancer Registrations in England. Population-Based Cohort Study. Tujuan penelitian Dragen, at.al (2012) mengevaluasi validitas dari diagnosis kanker dalam catatan perawatan kesehatan primer elektronik dengan membandingkan kejadian dan waktu diagnosis kanker antara the General Practice Research Database (GPRD) dengan Cancer Registrations (CR).

UU nomor 29 tahun 2004 tentang praktek kedokteran, pasal 46 menyebutkan setiap dokter dan dokter gigi dalam menjalankan praktek kedokteran wajib membuat rekam medis. Berdasarkan peraturan register kanker tahun 1992 (dalam Johns (2002)) bahwa register kanker berisi data sebagai berikut:

1) Informasi demografi dari masing-masing penderita kanker

2) Informasi pekerjaan atau riwayat pekerjaan dari individu yang terkena kanker

3) Informasi administratif, termasuk tanggal diagnosis dan sumber informasi

4) Data patalogi dari karakteristik kanker, termasuk tempat, stadium kanker, kejadian dan tipe pengobatan

\section{METODE PENELITIAN}

Penelitian ini merupakan penelitian deskriptif dengan pendekatan studi kasus. Teknik pengumpulan data menggunakan observasi, wawancara dan studi dokumentasi.

\section{HASIL PENELITIAN DAN PEMBA- HASAN}

\section{Sistem Pencatatan Data Pasien Kanker}

Sistem pencatatan data pasien kanker di Instalasi Kanker Tulip RSUP Dr.Sardjito dilakukan pada berkas rekam medis dan register kanker.

\section{Pencatatan data pada berkas rekam medis}

Proses pendaftaran pasien Instalasi Kanker Tulip dilakukan langsung di tempat pendaftaran di Instalasi Kanker Tulip. Hal ini dilakukan untuk mempercepat proses pelayanan kepada pasien yang hampir setiap hari datang untuk mendapatkan pengobatan kanker. Terdapat 7 (tujuh) formulir dasar yang digunakan untuk mencatat dan mendokumentasikan data pasien kanker di dalam berkas rekam medis pasien kanker. Masing-masing formulir tersebut adalah:

Formulir lembar poliklinik terdiri dari item data sosial yang terdapat di atas formulir, tanggal, jam, nama dokter, dan unitnya, hasil pemeriksaan dan diagnosis, dan nama terang dan tanda tangan dokter.

Formulir daftar masalah berisi identitas sosial pasien pada bagian atas formulir, dan tanggal penetapan masalah, kiriman atau rujukan pasien, masalah/ diagnosis, kode ICD, dan nama terang dokter yang memeriksa.

Formulir pemberian informasi ini sebagai bukti pelayanan yang diberikan tenaga kesehatan kepada pasien bahwa telah memberikan informasi terkait dengan tindakan pengobatan yang akan dilakukan kepada pasien. Item dalam formulir ini adalah selain identitas sosial pasien juga terdapat item untuk nama dokter pelaksana tindakan, tenaga kesehatan pemberi informasi, nama penerima informasi, jenis informasi yang disampaikan, isi informasi, paraf penerima informasi, pernyataan penerimaan informasi, dan tanda tangan pemberi dan penerima informasi.

Formulir persetujuan tindakan medis di Instalasi Kanker Tulip terdapat item identitas, pernyataan, nama tindakan medis, dan autentikasi.

Formulir asuhan keperawatan pelaksanaan kesehatan berisi item identitas sosial, tanggal dan jam pelayanan, riwayat penyakit, diagnosis keperawatan, perencanaan keperawatan, tindakan keperawatan, dan evaluasi perkembangan.

Jumlah formulir program kemoterapi menyesuaikan dengan jumlah tindakan kemoterapi yang telah diberikan kepada pasien. Formulir ini berisi data non medis yang berupa nama, nomor rekam medis, umur, tinggi badan, dan berat badan. Data medisnya berisi obat, dosis dan waktu pemberian obat, data monitor dan evaluasi (jam, tanda vital, efek samping, dan tindakan dari kegiatan monitoring yang dilakukan setelah pasien mendapatkan pengobatan), pengesahan (tanggal pelayanan 
dan tanda tangan dari perawat pelaksana dan dokter penanggungjawab).

Studi dokumentasi yang dilakukan terhadap item pada berkas rekam medis pasien kanker di Instalasi Kanker Tulip RSUP Dr.Sardjito:

Tabel 1. Hasil Studi Dokumentasi Isi Data Pada Berkas Rekam Medis pasien kanker

\begin{tabular}{|c|c|c|c|c|}
\hline No & Item Data & Ada & Tidak & $\begin{array}{c}\text { Terdapat Pada } \\
\text { Formulir }\end{array}$ \\
\hline 1 & Data demografi & & $\sqrt{ }$ & $\begin{array}{l}\text { Lembar } \\
\text { persetujuan } \\
\text { tindakan medis }\end{array}$ \\
\hline 2 & $\begin{array}{l}\text { Data terkait } \\
\text { penyakit kanker }\end{array}$ & & & \\
\hline & a. Tipe kanker & & $\sqrt{ }$ & $\begin{array}{l}\text { Biasa dituliskan } \\
\text { di Lembar } \\
\text { poliklinik }\end{array}$ \\
\hline & $\begin{array}{l}\text { b. Lokasi } \\
\text { kanker }\end{array}$ & & $\sqrt{ }$ & $\begin{array}{l}\text { Biasa dituliskan } \\
\text { di Lembar } \\
\text { poliklinik }\end{array}$ \\
\hline & $\begin{array}{l}\text { c. Metode } \\
\text { diagnosis }\end{array}$ & $\sqrt{ }$ & & $\begin{array}{l}\text { Pemberian } \\
\text { Informasi } \\
\text { Tindakan } \\
\text { Kedokteran }\end{array}$ \\
\hline & $\begin{array}{l}\text { d. Metode } \\
\text { pengobatan }\end{array}$ & & & $\begin{array}{l}\text { Pemberian } \\
\text { Informasi } \\
\text { Tindakan } \\
\text { Kedokteran }\end{array}$ \\
\hline & $\begin{array}{l}\text { e. Tahapan } \\
\text { pengobatan }\end{array}$ & $\sqrt{ }$ & & $\begin{array}{l}\text { Lembar program } \\
\text { kemoterapi }\end{array}$ \\
\hline
\end{tabular}

Data demografi belum terdapat pada berkas rekam medis, sedangkan untuk identitas seperti nama, jenis kelamin, dan umur ada disetiap bagian atas formulir rekam medis. Data demografi pasien kanker terdapat pada sistem informasi pasien yang terhubung on-line di seluruh bagian di RSUP Dr.Sardjito.

Untuk isi data tipe kanker dan lokasi kanker belum ada item data dalam formulir rekam medis yang meminta isian data tersebut, tetapi data tersebut biasanya dituliskan dalam formulir lembar poliklinik.

Pengelolaan berkas rekam medis di Instalasi Kanker Tulip tidak dilakukan assembling, coding, dan indeks. Dengan demikian belum adanya sistem jaminan kelengkapan pada berkas rekam medis.
Petugas pengelola berkas rekam medis di Instalasi Kanker Tulip RSUP Dr.Sardjito melibatkan 3 orang petugas rekam medis, dengan rincian 1 orang pegawai tetap RSUP Dr.Sardjito dan 2 orang lainnya adalah tenaga out-sourcing yang direkrut secara mandiri oleh Instalasi Kanker Tulip RSUP Dr.Sardjito. Tugas dari 1 orang pegawai tetap tersebut adalah melakukan pendaftaran terhadap pasien kanker dan pelaporan harian terkait kunjungan pasien. Untuk 2 orang petugas out-sourcing mempunyai tugas menyediakan berkas rekam medis sampai mendistribusikan ke klinik tujuan dan menyimpan kembali berkas rekam medis yang telah selesai digunakan.

\section{Pencatatan data pada register kanker}

Sistem pencatatan data pasien kanker di register kanker saat ini menggunakan aplikasi komputer yang bernama SRIKANDI (Sistem Registrasi Pasien Kanker di Indonesia).

SRIKANDI mulai digunakan pada Bulan Januari 2013, tetapi sekarang sudah akan berganti dengan aplikasi register kanker yang baru. Hal ini dilakukan untuk mengefektifkan sistem informasi dari register kanker.

Tujuan dari pencatatan data di register kanker ini untuk mengolah data medis dan non medis pasien kanker sehingga darinya dapat dihasilkan informasi mengenai riwayat penyakit kanker yang diderita pasien, mulai dari pasien tersebut datang pertama kali ke Instalasi Kanker Tulip RSUP Dr.Sardjito, dilanjutkan dengan proses penegakan diagnosis terhadapnya, hingga berapa lama pasien tersebut dapat bertahan dengan penyakit yang dideritanya.

Aplikasi register kanker atau dikenal dengan SRIKANDI terdiri dari 3 (tiga) menu, yaitu tab Patient, tab Tumor, dan tab Source \& Outcome. Berikut ini adalah gambar tampilan dari SRIKANDI:

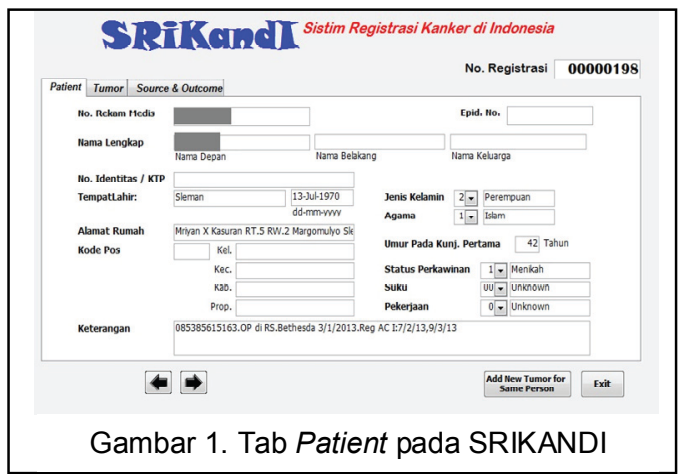



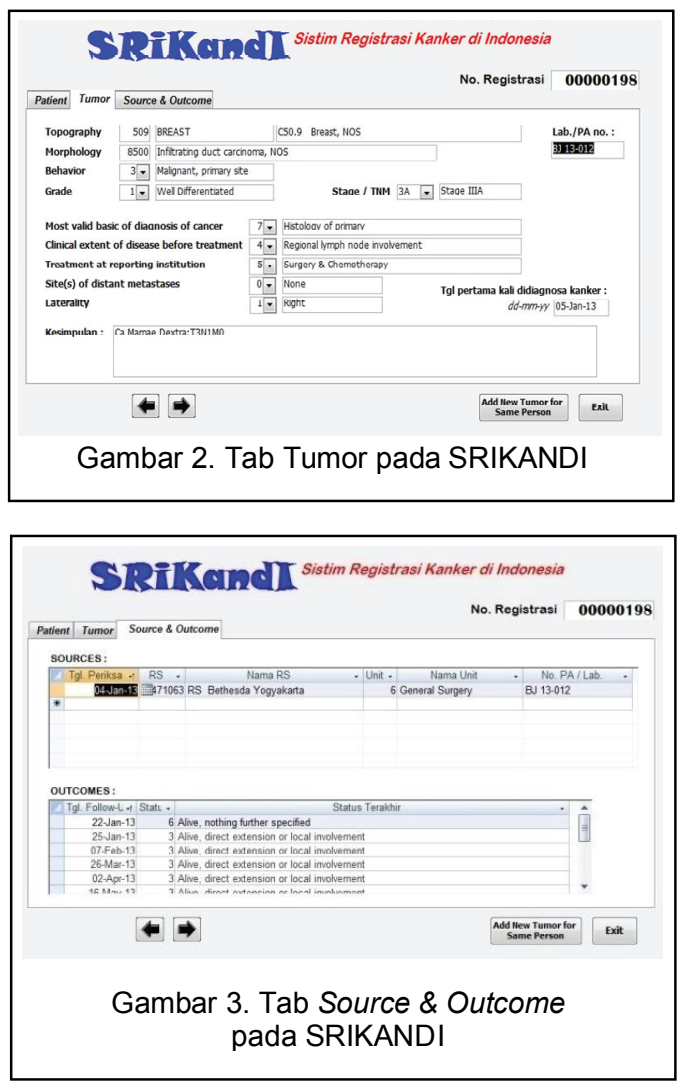

Sumber daya manusia yang mengerjakan register kanker di Instalasi Kanker Tulip RSUP Dr.Sardjito terdiri dari 1 orang petugas fulltimer dan 4 orang petugas part-timer.

Pencatatan data pasien kanker di register kanker dilakukan setiap hari kerja, setelah pelayanan pasien berakhir, tetapi apabila tidak selesai akan dilanjutkan pada hari berikutnya. Untuk kondisi yang sekarang pengisian data pasien pada register kanker belum dapat dilakukan secara realtime (setelah pasien berobat langsung dimasukkan datanya dalam register kanker). Hal ini dikarenakan berbagai kendala yang menghambat proses input data pasien ke dalam aplikasi register kanker tersebut.

Untuk saat ini, pembuatan register kanker baru berjalan sebatas mengumpulkan data pasien yang mendapatkan pelayanan di Instalasi Kanker Tulip. Proses pengolahan register kanker selanjutnya yaitu analisis tidak dilakukan. Proses analisis dilakukan jika ada permintaan tertentu, misal ada dokter yang membutuhkan data tersebut atau untuk kebutuhan penelitian. Hal tersebut sesuai dengan hasil wawancara yang dilakukan terhadap responden B sebagai berikut.
Biasanya kami hanya melakukan proses pengumulan data. Setelah data yang kami kumpulkan lengkap, kami tidak lantas melakukan export data ke excel dan SPSS.

Kami hanya melakukannya saat dibutuhkan saja, misal ada dokter yang membutuhkan data tersebut atau untuk kebutuhan penelitian.

Responden B (21-05-2013)

\section{Kelengkapan sistem pencatatan data}

Kelengkapan pada sistem pencatatan data pasien kanker di Intalasi Kanker Tulip ini melihat kelengkapan pengisian data pada berkas rekam medis dan register kanker (SRIKANDI).

a. Analisis kelengkapan data pada berkas rekam medis

Analisis kelengkapan dilakukan dengan check list terhadap 100 berkas rekam medis secara purposive sampling. Analisis dilakukan pada setiap lembar rekam medis berdasarkan komponen analisis kuantitatif (Huffman, 1995):

a) Identifikasi pada setiap lembar,

b) Laporan yang penting,

c) Autentikasi,

d) Pendokumentasian yang benar.

Untuk komponen analisis identifikasi, laporan yang penting, dan autentifikasi (komponen a $-\mathrm{c}$ masing-masing lembar di atas) dilakukan analisis berdasarkan terisi dan tidak terisi (TDK). Terisi dianalisis lagi menjadi terisi lengkap (L) dan terisi tidak lengkap (TL). Sedangkan untuk komponen analisis pendokumentasian yang benar (komponen $\mathrm{d}$ masing-masing lembar di atas) dilakukan analisis berdasarkan benar (B) dan tidak benar (TB), Tidak ada pembetulan kesalahan (TPK), dan tidak didokumentasikan (TD). Hasil analisis kuantitatif pada 100 berkas rekam medis:

Tabel 2. Analisis Kuantitatif 3 Komponen Pada Lembar Poliklinik

\begin{tabular}{|c|l|c|c|c|c|}
\hline \multirow{2}{*}{ No } & \multirow{3}{*}{ Komponen Analisis } & \multicolumn{4}{|c|}{ Adanya Lembar } \\
\cline { 3 - 5 } & & \multicolumn{3}{|c|}{ Ada Lembar } & Tidak \\
\cline { 3 - 5 } & & \multicolumn{2}{|c|}{ Terisi } & Tidak & Ada \\
\cline { 3 - 4 } & & $\mathbf{L}$ & $\mathbf{T L}$ & Terisi & Lembar \\
$\mathbf{( \% )}$ & $\mathbf{( \% )}$ & $\mathbf{( \% )}$ & $\mathbf{( \% )}$ \\
\hline 1 & Identifikasi & 17 & 12 & 64 & 7 \\
\hline 2 & Laporan yang penting & 29 & 2 & 62 & 7 \\
\hline 3 & Autentikasi & 22 & 6 & 65 & 7 \\
\hline
\end{tabular}


Dari 100 sampel ada 7 berkas rekam medis yang tidak ditemukan lembar polikiniknya. Dari 93 Lembar poliklinik dilakukan analisis untuk komponen pendokumentasiannya.

Tabel 3. Analisis Kuantitatif Komponen Pendokumentasian Pada Lembar Poliklinik

\begin{tabular}{|c|c|c|c|c|c|}
\hline \multirow[b]{2}{*}{ No } & \multirow[b]{2}{*}{ Komponen Analisis } & \multicolumn{3}{|c|}{ Ada Pendokumentasian } & \multirow{2}{*}{$\begin{array}{l}\text { TD } \\
\text { (\%) }\end{array}$} \\
\hline & & $\begin{array}{c}\text { B } \\
(\%)\end{array}$ & $\begin{array}{l}\text { TB } \\
(\%)\end{array}$ & $\begin{array}{l}\text { TPK } \\
\text { (\%) }\end{array}$ & \\
\hline 1 & $\begin{array}{l}\text { Pendokumentasian } \\
\text { yang benar }\end{array}$ & 0 & 0 & 33,3 & 66,7 \\
\hline
\end{tabular}

Terdapat 33,3\% lembar poliklinik yang diisi tanpa ada pembetulan kesalahan dan $66,7 \%$ yang tidak ada isian datanya.

Tabel 4. Analisis Kuantitatif 3 Komponen Pada Lembar Pemeriksaan Laboratorium

\begin{tabular}{|c|l|c|c|c|c|}
\hline \multirow{2}{*}{ No } & \multirow{3}{*}{ Komponen Analisis } & \multicolumn{4}{|c|}{ Adanya Lembar } \\
\cline { 3 - 5 } & & \multicolumn{3}{|c|}{ Ada Lembar } & Tidak \\
\cline { 3 - 5 } & & $\begin{array}{c}|c| \\
\text { Terisi }\end{array}$ & $\begin{array}{c}\text { TL } \\
\text { Ada }\end{array}$ & $\begin{array}{c}\text { Terisi } \\
\mathbf{( \% )}\end{array}$ & Lembar \\
& & 87 & 2 & 0 & 11 \\
\hline 1 & Identifikasi & \\
\hline 2 & Laporan yang penting & 89 & 0 & 0 & 11 \\
\hline 3 & Autentikasi & 80 & 8 & 1 & 11 \\
\hline
\end{tabular}

Dari 100 berkas rekam medis ditemukan 11 berkas rekam medis yang tidak ada lembar pemeriksaan laboratoriumnya.

Tabel 5. Analisis Kuantitatif Komponen Pendokumentasian Pada Lembar Pemeriksaan Laboratorium

\begin{tabular}{|c|c|c|c|c|c|}
\hline \multirow[b]{2}{*}{ No } & \multirow[b]{2}{*}{ Komponen Analisis } & \multicolumn{3}{|c|}{ Ada Pendokumentasian } & \multirow[b]{2}{*}{$\begin{array}{l}\text { TD } \\
(\%)\end{array}$} \\
\hline & & $\begin{array}{c}\text { B } \\
(\%)\end{array}$ & $\begin{array}{c}\text { TB } \\
(\%)\end{array}$ & $\begin{array}{l}\text { TPK } \\
(\%)\end{array}$ & \\
\hline 1 & $\begin{array}{l}\text { Pendokumentasian } \\
\text { yang benar }\end{array}$ & 5,6 & 0 & 94,4 & 0 \\
\hline
\end{tabular}

Analisis pendokumentasian yang benar dilakukan terhadap 89 lembar pemeriksaan laboratorium. Hasilnya terdapat 94,4\% lembar pemeriksaan lab yang terisi dan tidak terdapat pembetulan kesalahan, dan 5,6\% lembar yang terisi terdapat pembetulan kesalahan yang dilakukan dengan benar.

Tabel 6. Analisis Kuantitatif 3 Komponen Pada Lembar Daftar Masalah

\begin{tabular}{|c|l|c|c|c|c|}
\hline \multirow{2}{*}{ No } & \multirow{3}{*}{ Komponen Analisis } & \multicolumn{4}{|c|}{ Adanya Lembar } \\
\cline { 3 - 5 } & & \multicolumn{3}{|c|}{ Ada Lembar } & Tidak \\
\cline { 3 - 5 } & & \multicolumn{2}{|c|}{ Terisi } & Tidak & Ada \\
\cline { 3 - 4 } & & $\begin{array}{c}\text { TL } \\
\text { (\%) }\end{array}$ & $\begin{array}{c}\text { Terisi } \\
\mathbf{( \% )}\end{array}$ & $\begin{array}{c}\text { Lembar } \\
\mathbf{( \% )}\end{array}$ \\
\hline 1 & Identifikasi & 26 & 26 & 46 & 2 \\
\hline 2 & Laporan yang & 1 & 48 & 49 & 2 \\
\hline 3 & penting & 11 & 51 & 36 & 2 \\
\hline
\end{tabular}

Dari 100 berkas rekam medis ditemukan 2 berkas rekam medis yang tidak ada lembar daftar masalahnya.

Tabel 7. Analisis Kuantitatif Komponen Pendokumentasian Pada Lembar Daftar Masalah

\begin{tabular}{|c|c|c|c|c|c|}
\hline \multirow[b]{2}{*}{ No } & \multirow[b]{2}{*}{ Komponen Analisis } & \multicolumn{3}{|c|}{ Ada Pendokumentasian } & \multirow{2}{*}{$\begin{array}{l}\text { TD } \\
(\%)\end{array}$} \\
\hline & & $\begin{array}{c}\text { B } \\
(\%)\end{array}$ & $\begin{array}{l}\text { TB } \\
(\%)\end{array}$ & $\begin{array}{l}\text { TPK } \\
(\%)\end{array}$ & \\
\hline 1 & $\begin{array}{l}\text { Pendokumentasian } \\
\text { yang benar }\end{array}$ & 0 & 0 & 68,4 & 31,6 \\
\hline
\end{tabular}

Dari 98 lembar terdapat 68,4\% lembar daftar masalah yang diisi tanpa ada pembetulan kesalahan dan $31,6 \%$ yang tidak ada isian datanya.

\section{Lembar Pemberian Informasi Tindakan Kedokteran \\ Dari 100 berkas rekam medis ditemukan $76 \%$ berkas yang tidak ada lembar pemberian informasi tindakan kedokteran. Dari 24\% lembar yang ada sebanyak $4 \%$ terisi leng- kap, $10 \%$ terisi tidak lengkap, dan $10 \%$ ada lembar tetapi datanya tidak terisi.}

Tabel 8. Hasil Analisis Kuantitatif 3 Komponen Pada Lembar Pemberian Informasi Tindakan Kedokteran

\begin{tabular}{|c|c|c|c|c|c|}
\hline \multirow{4}{*}{ No } & \multirow{4}{*}{ Komponen Analisis } & \multicolumn{4}{|c|}{ Adanya Lembar } \\
\hline & & \multicolumn{3}{|c|}{ Ada Lembar } & \multirow{3}{*}{$\begin{array}{c}\text { Tidak } \\
\text { Ada } \\
\text { Lembar } \\
(\%)\end{array}$} \\
\hline & & \multicolumn{2}{|c|}{ Terisi } & \multirow{2}{*}{$\begin{array}{c}\text { Tidak } \\
\text { Terisi } \\
(\%)\end{array}$} & \\
\hline & & $\begin{array}{c}\mathrm{L} \\
(\%)\end{array}$ & $\begin{array}{l}\text { TL } \\
(\%)\end{array}$ & & \\
\hline 1 & Identifikasi & 4 & 10 & 10 & 76 \\
\hline 2 & $\begin{array}{l}\text { Laporan yang } \\
\text { penting }\end{array}$ & 8 & 6 & 10 & 76 \\
\hline 3 & Autentikasi & 11 & 2 & 11 & 76 \\
\hline
\end{tabular}

Dari 24 lembar pemberian informai tindakan yang ada pada berkas rekam medis dilakukan analisis pendokumentasiannya. 
Tabel 9. Hasil Analisis Kuantitatif Komponen Pendokumentasian Pada Lembar Pemberian Informasi Tindakan Kedokteran

\begin{tabular}{|c|c|c|c|c|c|}
\hline \multirow[b]{2}{*}{ No } & \multirow[b]{2}{*}{ Komponen Analisis } & \multicolumn{3}{|c|}{ Ada Pendokumentasian } & \multirow{2}{*}{$\begin{array}{l}\text { TD } \\
(\%)\end{array}$} \\
\hline & & $\begin{array}{c}\text { B } \\
(\%)\end{array}$ & $\begin{array}{l}\text { TB } \\
(\%)\end{array}$ & $\begin{array}{l}\text { TPK } \\
(\%)\end{array}$ & \\
\hline 1 & $\begin{array}{l}\text { Pendokumentasian } \\
\text { yang benar }\end{array}$ & 0 & 0 & 58,3 & 41,7 \\
\hline
\end{tabular}

Lembar Persetujuan Tindakan Medis

Dari 100 berkas rekam medis ditemukan $74 \%$ berkas rekam medis yang tidak terdapat lembar persetujuan tindakan medis dan $26 \%$ berkas rekam medis pasien kanker yang ada lembar persetujuan tindakan medisnya.

Tabel 10. Hasil Analisis Kuantitatif 3 Komponen Pada Lembar Persetujuan Tindakan Medis

\begin{tabular}{|c|c|c|c|c|c|}
\hline \multirow{4}{*}{ No } & \multirow{4}{*}{ Komponen Analisis } & \multicolumn{4}{|c|}{ Adanya Lembar } \\
\hline & & \multicolumn{3}{|c|}{ Ada Lembar } & \multirow{3}{*}{$\begin{array}{c}\text { Tidak } \\
\text { Ada } \\
\text { Lembar } \\
(\%)\end{array}$} \\
\hline & & \multicolumn{2}{|c|}{ Terisi } & \multirow{2}{*}{$\begin{array}{c}\text { Tidak } \\
\text { Terisi } \\
\text { (\%) }\end{array}$} & \\
\hline & & $\begin{array}{c}\text { L } \\
(\%)\end{array}$ & $\begin{array}{l}\mathrm{TL} \\
\text { (\%) }\end{array}$ & & \\
\hline 1 & Identifikasi & 10 & 16 & 0 & 74 \\
\hline 2 & $\begin{array}{l}\text { Laporan yang } \\
\text { penting }\end{array}$ & 15 & 11 & 0 & 74 \\
\hline 3 & Autentikasi & 1 & 25 & 0 & 74 \\
\hline
\end{tabular}

Tabel 11. Hasil Analisis Kuantitatif Komponen Pendokumentasian Pada Lembar Persetujuan Tindakan Medis

\begin{tabular}{|c|c|c|c|c|c|}
\hline \multirow[b]{2}{*}{ No } & \multirow[b]{2}{*}{ Komponen Analisis } & \multicolumn{3}{|c|}{ Ada Pendokumentasian } & \multirow{2}{*}{$\begin{array}{l}\text { TD } \\
(\%)\end{array}$} \\
\hline & & $\begin{array}{c}\text { B } \\
(\%)\end{array}$ & $\begin{array}{l}\text { TB } \\
(\%)\end{array}$ & $\begin{array}{l}\text { TPK } \\
(\%)\end{array}$ & \\
\hline 1 & $\begin{array}{l}\text { Pendokumentasian } \\
\text { yang benar }\end{array}$ & 0 & 0 & 100 & 0 \\
\hline
\end{tabular}

Tabel 12. Hasil Analisis Kuantitatif 3 Komponen Pada Lembar Asuhann Keperawatan Pelaksanaan Kesehatan

\begin{tabular}{|c|l|c|c|c|c|}
\hline \multirow{2}{*}{ No } & \multirow{2}{*}{ Komponen Analisis } & \multicolumn{4}{|c|}{ Adanya Lembar } \\
\cline { 3 - 5 } & & \multicolumn{3}{|c|}{ Ada Lembar } & Tidak \\
\cline { 3 - 5 } & & \multicolumn{2}{|c|}{ Terisi } & Tidak & Ada \\
\cline { 3 - 5 } & & $\mathbf{L}$ & $\mathbf{T L}$ & $\begin{array}{c}\text { Terisi } \\
\text { Lembar } \\
\mathbf{( \% )}\end{array}$ & $\mathbf{( \% )}$ \\
\hline 1 & Identifikasi & 17 & 12 & 64 & 7 \\
\hline 2 & Laporan yang & 29 & 2 & 62 & 7 \\
& penting & & & & \\
\hline 3 & Autentikasi & 22 & 6 & 65 & 7 \\
\hline
\end{tabular}

Dari 100 berkas rekam medis ada 7\% berkas yang tidak ada lembar asuhan keperawatan. Dari 93 berkas rekam medis dilakukan analisis pendokumentasian:

Tabel 13. Hasil Analisis Kuantitatif Komponen Pendokumentasian Pada Lembar Asuhan Keperawatan Pelaksanaan Kesehatan

\begin{tabular}{|c|l|c|c|c|c|}
\hline \multirow{2}{*}{ No } & Komponen Analisis & \multicolumn{2}{|c|}{ Ada Pendokumentasian } & \\
\cline { 3 - 5 } & & $\begin{array}{c}\text { B } \\
\text { T\%) }\end{array}$ & $\begin{array}{c}\text { TB } \\
\mathbf{( \% )}\end{array}$ & $\begin{array}{c}\text { TPK } \\
\mathbf{( \% )}\end{array}$ & $(\%)$ \\
\hline 1 & $\begin{array}{l}\text { Pendokumentasian } \\
\text { yang benar }\end{array}$ & 0 & 0 & 33,3 & 66,7 \\
\hline
\end{tabular}

Tabel 14. Hasil Analisis Kuantitatif 3 Komponen Pada Lembar Program Kemoterapi

\begin{tabular}{|c|c|c|c|c|c|}
\hline \multirow{4}{*}{ No } & \multirow{4}{*}{ Komponen Analisis } & \multicolumn{4}{|c|}{ Adanya Lembar } \\
\hline & & \multicolumn{3}{|c|}{ Ada Lembar } & \multirow{3}{*}{$\begin{array}{c}\text { Tidak } \\
\text { Ada } \\
\text { Lembar } \\
(\%)\end{array}$} \\
\hline & & \multicolumn{2}{|c|}{ Terisi } & \multirow{2}{*}{$\begin{array}{c}\text { Tidak } \\
\text { Terisi } \\
(\%)\end{array}$} & \\
\hline & & $\begin{array}{c}L \\
(\%)\end{array}$ & $\begin{array}{l}\text { TL } \\
(\%)\end{array}$ & & \\
\hline 1 & Identifikasi & 43 & 6 & 0 & 51 \\
\hline 2 & $\begin{array}{l}\text { Laporan yang } \\
\text { penting }\end{array}$ & 45 & 4 & 0 & 51 \\
\hline 3 & Autentikasi & 5 & 43 & 1 & 51 \\
\hline
\end{tabular}

100 berkas rekam medis ditemukan $51 \%$ berkas rekam medis yang tidak ada lembar program kemoterapi. Dari 49 lembar program kemoterapi dilakukan analisis pendokumentasiannya:

Tabel 15. Hasil Analisis Kuantitatif Komponen Pendokumentasian Pada Lembar Program Kemoterapi

\begin{tabular}{|c|l|c|c|c|c|}
\hline \multirow{2}{*}{ No } & \multirow{2}{*}{ Komponen Analisis } & \multicolumn{3}{|c|}{ Ada Pendokumentasian } & \multirow{2}{*}{ TD } \\
\cline { 3 - 5 } & & $\begin{array}{c}\text { B } \\
(\%)\end{array}$ & $\begin{array}{c}\text { TB } \\
(\%)\end{array}$ & $\begin{array}{c}\text { TPK } \\
(\%)\end{array}$ & $(\%)$ \\
\hline \multirow{2}{*}{1} & $\begin{array}{l}\text { Pendokumentasian } \\
\text { yang benar }\end{array}$ & 0 & 0 & 100 & 0 \\
\hline
\end{tabular}

b. Analisis Kelengkapan Pada Register Kanker

Analisis dilakukan dengan melihat keterisian data pada setiap item menu pada register kanker. Komponen analisis yaitu Terisi Lengkap (L), Terisi Tidak Lengkap (TL), dan Tidak Terisi (TT). 


\section{Menu Identifikasi pasien}

Tabel 16. Hasil Analisis Isi Item Identitas Tab Pasien Pada Register Kanker

\begin{tabular}{|c|l|c|c|c|}
\hline \multirow{2}{*}{ No } & \multirow{2}{*}{ Nama Item } & \multicolumn{3}{|c|}{ Adanya Lembar } \\
\cline { 3 - 5 } & & \multicolumn{2}{|c|}{ Terisi } & Tidak \\
\cline { 3 - 5 } & & $\begin{array}{c}\text { TL } \\
\text { Terisi }\end{array}$ & $\begin{array}{c}\text { (\%) } \\
(\%)\end{array}$ \\
\hline 1 & Nomor Register & 100 & 0 & 0 \\
\hline 2 & Nomor Rekam Medis & 100 & 0 & 0 \\
\hline 3 & Nama Lengkap & 99 & 0 & 1 \\
\hline 4 & Nama Belakang & 40 & 0 & 60 \\
\hline 5 & Nama Keluarga & 1 & 0 & 99 \\
\hline 6 & Nomor Epid & 1 & 0 & 99 \\
\hline 7 & Nomor Identitas/KTP & 3 & 0 & 97 \\
\hline 8 & Tempat Lahir & 99 & 0 & 1 \\
\hline 9 & Jenis Kelamin & 100 & 0 & 0 \\
\hline 10 & Agama & 100 & 0 & 0 \\
\hline 11 & Alamat Rumah & 100 & 0 & 0 \\
\hline 12 & Kelurahan & 9 & 0 & 91 \\
\hline 13 & Kecamatan & 6 & 0 & 94 \\
\hline 14 & Kabupaten & 7 & 0 & 93 \\
\hline 15 & Propinsi & 7 & 0 & 93 \\
\hline 16 & Kode Pos & 7 & 0 & 93 \\
\hline 17 & Umur Pada Kunjungan Pertama & 95 & 0 & 5 \\
\hline 18 & Status Perkawinan & 97 & 0 & 3 \\
\hline 19 & Suku & 2 & 0 & 98 \\
\hline 20 & Pekerjaan & 31 & 0 & 69 \\
\hline 21 & Keterangan & 0 & 13 \\
\hline
\end{tabular}

Dari 100 data register kanker ditemukan beberapa item identitas sudah terisi lengkap $100 \%$. Selain itu, dari 100 data register kanker terdapat item identitas pasien yang tidak terisi mencapai lebih dari $90 \%$.

\section{Menu Kondisi Tumor}

Dari 100 data register kanker ditemukan beberapa item kondisi tumor pasien sudah terisi lengkap $100 \%$ dan terdapat item yang tidak terisi mencapai $62 \%$.

Tabel 17. Hasil Analisis Isi Item Kondisi Tumor Tab Tumor Pada Register Kanker

\begin{tabular}{|c|l|c|c|c|}
\hline \multirow{2}{*}{ No } & \multirow{2}{*}{ Nama Item } & \multicolumn{3}{|c|}{ Adanya Lembar } \\
\cline { 3 - 5 } & & \multicolumn{2}{|c|}{ Terisi } & Tidak \\
\cline { 3 - 4 } & & $\mathbf{L}$ & $\mathbf{T L}$ & Terisi \\
$\mathbf{( \% )}$ & $\mathbf{( \% )}$ & $\mathbf{( \% )}$ \\
\hline 1 & Nomor Register & 100 & 0 & 0 \\
\hline 2 & Topography & 100 & 0 & 0 \\
\hline 3 & Morphologi & 99 & 0 & 1 \\
\hline 4 & Behaviour & 100 & 0 & 0 \\
\hline
\end{tabular}

\begin{tabular}{|c|l|c|c|c|}
\hline \multirow{2}{*}{ No } & \multirow{2}{*}{ Nama Item } & \multicolumn{3}{|c|}{ Adanya Lembar } \\
\cline { 3 - 5 } & & \multicolumn{2}{|c|}{ Terisi } & Tidak \\
\cline { 3 - 4 } & & $\begin{array}{c}\text { L } \\
\mathbf{( \% )}\end{array}$ & $\begin{array}{c}\text { TL } \\
\mathbf{( \% )}\end{array}$ & $\begin{array}{c}\text { Terisi } \\
\mathbf{( \% )}\end{array}$ \\
\hline 5 & Grade & 91 & 0 & 9 \\
\hline 6 & Stage/TNM & 38 & 0 & 62 \\
\hline 7 & Nomor Lab/PA & 96 & 0 & 4 \\
\hline 8 & Most valid of diagnosis of & 97 & 0 & 3 \\
\hline 9 & $\begin{array}{l}\text { Clinical extent of disease before } \\
\text { treatment }\end{array}$ & 74 & 0 & 26 \\
\hline 10 & $\begin{array}{l}\text { Trearment at reporting } \\
\text { institution }\end{array}$ & 88 & 0 & 12 \\
\hline 11 & Site(s) of distant metastases & 45 & 0 & 55 \\
\hline 12 & Laterality & 85 & 0 & 15 \\
\hline 13 & Tanggal pertama kali & 99 & 0 & 1 \\
\hline 14 & Kisiagnosis kanker & & & \\
\hline
\end{tabular}

Menu source \& outcome

Tabel 18. Hasil Analisis Isi Item Sumber \& Hasil Penanganan Tumor Tab Source \& Outcome

\begin{tabular}{|c|c|c|c|c|}
\hline \multirow{3}{*}{ No } & \multirow{3}{*}{ Nama Item } & \multicolumn{3}{|c|}{ Adanya Lembar } \\
\hline & & \multicolumn{2}{|c|}{ Terisi } & \multirow{2}{*}{$\begin{array}{c}\text { Tidak } \\
\text { Terisi } \\
\text { (\%) }\end{array}$} \\
\hline & & $\begin{array}{c}\mathrm{L} \\
(\%)\end{array}$ & $\begin{array}{l}\text { TL } \\
\text { (\%) }\end{array}$ & \\
\hline 1 & Nomor register & 100 & 0 & 0 \\
\hline \multicolumn{5}{|c|}{ Item Source } \\
\hline 1 & Tanggal periksa & 100 & 0 & 0 \\
\hline 2 & Kode rumah sakit & 75 & 0 & 25 \\
\hline 3 & Nama rumah sakit & 76 & 0 & 24 \\
\hline 4 & Unit & 96 & 0 & 4 \\
\hline 5 & Nama unit & 99 & 0 & 1 \\
\hline 6 & Nomor PA/Lab & 99 & 0 & 1 \\
\hline \multicolumn{5}{|c|}{ Item Outcomes } \\
\hline 1 & Tanggal follow-up & 100 & 0 & 100 \\
\hline 2 & Status & 100 & 0 & 0 \\
\hline 3 & Status terakhir & 100 & 0 & 0 \\
\hline
\end{tabular}

Dari 100 data register kanker ditemukan beberapa item sumber dan hasil pelayanan kanker sudah terisi lengkap $100 \%$ dan ada item data yang tidak terisi nilainya mencapai $100 \%$.

\section{Kendala Pengelolaan Sistem Pencatatan}

\section{Kendala sistem pencatatan pada berkas rekam medis}

Kendala sistem pencatatan data pasien pada berkas rekam medis di Instalasi Kanker Tulip 
yaitu dari sumber daya manusia, kebijakan, dan fasilitas.

2. Kendala sistem pencatatan pada register pasien kanker

Kendala sistem pencatatan data pasien pada register kanker di Instalasi Kanker Tulip yaitu sumber data dan kebijakan.

\section{SIMPULAN}

1. Sistem pencatatan data pasien kanker di Instalasi Kanker Tulip RSUP Dr.Sardjito dilakukan menggunakan berkas rekam medis dan register kanker.

2. Persentase ketidakterisian pada berkas rekam medis paling tinggi terdapat pada lembar poliklinik dan asuhan keperawatan nilainya mencapai lebih dari $60 \%$. Persentase ketidakterisian pada register kanker paling tinggi terdapat pada item nama keluarga, nomor epidemologi, dan tanggal follow-up yang nilainya mencapai lebih dari $90 \%$.

3. Kendala sistem pencatatan data pasien kanker pada berkas rekam medis adalah sumber daya manusia, prosedur, dan fasilitas. Sedangkan kendala sistem pencatatan data pada register kanker sumber data dan prosedur.

\section{DAFTAR PUSTAKA}

Abdelhak, M., Hanken, M A., Jacobs, E., 2007. Health Information Management of a Stategic Resource. WB Sanders Company. Sedney.

Belgian Cancer Registry., -. Belgian Cancer Registry: Kanker Registry. [tersedia di www. kankerregister.org/Kankerregistratie < akses tanggal 24 April 2013>]

Budi, S.C., 2011. Manajemen Unit Kerja Rekam Medis. Yogyakarta: Quantum Sinergis Media.
Dregan, A., Moller, H., Murray-Thomas, T., Guliford, M.C., 2012. The International Journal of Cancer Epidemiology, Detectin, and Prevention: Validiti of Cancer Diagnosis in a Primary Care Database Compared with Linked Cacer Registrations in England. [tersedia di www.cacerepidemology.net $<$ akses tanggal 15 April 2013>].

Hasibuan, M, SP., 2008. Manajemen Sumber Daya Manusia. Jakarta: Bumi Aksara.

Hatta, G R., 2008. Pedoman Manajemen Informasi Kesehatan di Sarana Pelayanan Kesehatan. Jakarta: UI-PRESS.

Huffman, E K., 1994. Health Information Management. Physicians Record Compampany. Illyones.

Johns, M L., 2002. Health Information Management Technology. AHIMA. Illyones.

Konsil Kedokteran Indonesia., 2006. Manual Persetujuan Tindakan Kedokteran. Jakarta: Konsil Kedokteran Indonesia.

Nawawi, H., 2003. Metode Penelitian Bidang Sosial. Yogyakarta: Gadjah Mada University Press.

Sarjadi., 1992. Registrasi Kanker Dalam Konteks Penanggulangan Penyakit Kanker. Semarang: Universitas Diponegoro.

Sugiyono., 2009. Metodologi Penelitian Kuantitatif, Kualitatif dan R\&D. Bandung: Alfabeta.

Syamsi, I., 2004. Pokok-Pokok Organisasi dan Manajemen. Jakarta: Rineka Cipta.

WHO., 2002. Medical Records Manual. [tersedia di www.pro.who.int < akses tanggal 14 April $2013>$ ]. 